\title{
BOURDIEU CAPITALS AND LEADERSHIP: THE CASE OF DESIGN CONSULTANT FIRMS' MANAGERS IN THE MALAYSIAN CONSTRUCTION INDUSTRY
}

\author{
Mohd Hisham Ariffin ${ }^{1 *}$, Abdul Rahman Abdul Rahim², Ruslan Affendy Arshad ${ }^{1}$, and Ruzaini Zahari ${ }^{3}$, \\ ${ }^{1}$ Faculty of Architecture, Planning and Surveying, Universiti Teknologi MARA, 40450, Shah Alam, Selangor, Malaysia \\ ${ }^{2}$ Faculty of Business and Management, Universiti Teknologi MARA, 40450, Shah Alam, Selangor, Malaysia \\ ${ }^{3}$ Centre of Postgraduate Studies (Graduate Research Assistant), Faculty of Architecture, Planning and Surveying, Universiti Teknologi \\ MARA, 40450, Shah Alam, Selangor, Malaysia
}

\begin{abstract}
The creative products of Malaysian design firms are critical for sustained competitiveness in the increasing globalised and local construction market. These products are derived from the collaborative efforts of the design leaders and their subordinates. Owner-managers of design firms are aware of the role of their leadership in increasing the productivity of their creativity workers. Knowledge of effective leadership traits has initially guided leadership development and sustainability. Later theories such as charismatic theories and leader-member exchange theories have a common theoretical paradigm of leader-follower relations. A novel approach to this leadership theoretical paradigm is replacing relevant leaders' traits with Bourdieu capitals that effectively influence their followers. This paper reports the findings of interviews with subordinates in Malaysian architecture, civil engineering and landscape architecture consultant firms regarding the influence of the superior's Bourdieu capitals upon their creativity. Qualitative thematic coding analysis of the interview transcripts generated the relevant Bourdieu capital categories and theme. The leader's human, emotional, leadership, cultural and social capitals were found to influence the subordinate's creativity motivation. The data indicate a common theme of followers' creativity motivation through learning from leader's superior human capital. The learning is aided by the leader's emotional capital. Thus, Bourdieu capitals offer an innovative perspective in studying and possibly quantifying leaders' influence upon their followers.
\end{abstract}

\section{Introduction}

Many nations including Malaysia have increasingly been introducing more liberalisation policies than protection policies for international services trade in the $21^{\text {st }}$ century. Although the liberalisation of services trade is relatively small in the professional services sector, it is predicted to grow in the future [1]. Malaysia has free trade agreements such as the ASEAN Free Trade Area (AFTA) agreement and bilateral agreements with the European Union, Korea and Australia among others. [2, 3]. The future of Malaysian professional services business such as architecture and engineering design services is one of increasing competition locally and internationally and hence must have competitive aspects such as quality creative design and product deliverables. Although creativity is a mix of novelty and usefulness, it does not necessarily equate with an effective design. Yet, creativity is integral to the design process [4-7]. Hence, a design firm's competitiveness is viewed as partly dependent upon the creativity of its designers. In architecture and civil engineering consultant firms, the principal and senior designers often lead and collaborate with a team of less experienced subordinate designers to generate bespoke designs for the clients. The subordinate designers' creativity and knowledge is integral to producing competitive designs. Research found that the leader's behaviour plays an important role in creativity enhancement of the subordinates [8-11].

\section{Past Researches}

The role of leadership in promoting creativity among his followers in organizations has been researched from perspectives of the impact of superiors' behaviours and traits upon the subordinates' behaviour. An emerging approach in leadership research is the influencing role of a leader's tangible and intangible resources on his followers. These resources include social network diversity, personal qualities, and experiential knowledge. Bourdieu [12] calls the leaders' intangible resources as capitals. A high amount of these capitals can signal the leader's credibility both within and outside his organization [13]. The capitals are relevant to a sociocultural framework that Bourdieu (1986) labels as "fields of practice". A Bourdieu field is a structured social space with a unique doxa (rules of the 'game') and habitus

* Corresponding author: mhisham238@salam.uitm.edu.my 
(psychological schemas of thoughts, actions and dispositions). A person dwells in many fields such a field of familial relationships, a field of employment, a field of community etc. Individuals in a field continuously jostle for positions or status using their capitals. A person sustains, accumulates or diminishes his set of capitals through his life actions. Capitals have varying usefulness in various fields of practices. For example, social capital may be more beneficial to actors in the political field as compared with those in the creative and manufacturing fields [12, 14]

Past researches such as Santos-Rodrigues et al. [15] and Liu et al. [16] studied the influence of Bourdieu's capitals by focusing on one or two capitals in their research instead of using a combination of Bourdieu's capitals. Studies by Landry et al [17], Perez-Luno et al [18], and $\mathrm{Gu}$ et al [19] in education and manufacturing indicated that social capital exerted a clear influence on innovation and creativity. Bourdieu capitals used for leadership studies are in education [20], sports [21], and community researches [22]. Evidences of leadership studies using Bourdieu capitals in other fields include business [23], ethnic studies [24] and politics [25]. No leadership studies based on Bourdieu capitals has been carried out upon the creative practitioners in the construction industry.

\section{Methodology}

This is an exploratory qualitative interview research. It forms part of a larger study on the influence of the superior's Bourdieu's capitals on subordinates' creativity in design consultant firms from the Malaysian construction industry. The purposive sample of respondents across Malaysia were five design subordinates in architecture design consultant firms, six design subordinates from civil engineering design consultant firms and six design subordinates in landscape design consultant firms. Eight respondents were male. All respondents have five years minimum working experience in their respective professions. The respondents were chosen because they inhabit the same 'field' (construction industry) with its unique doxa. They are also Malaysians which means that they have a common habitus albeit from different ethnicities (Bourdieu, 1986). Theoretical saturation was achieved at the fifteenth respondent.

The fourth author interviewed the respondents by telephone. The respondents were asked to give their views on statements describing their leaders' characteristics that can motivate them to be more creative. The interviews were audio recorded and transcribed for analysis. Qualitative Thematic Coding was used where the Bourdieu theory of field is the analytical basis to uncover the meaning units and categories of leadership characteristics. Eighteen relevant meaning units were identified from the data and then grouped into five Bourdieu capital categories. The transcripts, meaning units and categories were then analyzed again to generate a theme. The analysis results by the first author are reviewed by the second and third authors to obtain robustness.

\section{Findings}

The following sections report the relevant capitals and theme generated from the analysis, and the discussion of the findings.

\subsection{Category Findings}

Category coding analysis of the interview transcripts generated nineteen meaning units. Five capital categories were identified from the consolidation of the meaning units. These are Social, Human, Cultural, Emotional and Political Capitals. However, only Human Capital and Emotional Capital are reported here due to their relevance with the generated thematic finding (Table 1).

Human capital refers to the subordinate's perception of experiential knowledge and institutionalized recognition of skills and experiences of his or her leader. Eight meaning units comprising this category are (1) subordinates learning from leader's experience and knowledge, (2) subordinate's confidence about leader's experiential knowledge, (3) reciprocal/collaborative learning. (4) leader guiding of subordinate's learning, (5) role modeling of leader by subordinates, (6) leader's accredited knowledge, (7) leader's reputation, and (8) leader's demotivating influence.

Emotional capital is about the subordinate's perception of the leader's emotional resources in the form of emotional support, expenditure of time, attention, care and concern available to his/her subordinates. Four meaning units comprising this category are (1) respectfulness, (2) possessing likeable and inspiring

Table 1 Theme-relevant Bourdieu Capital Categories

\begin{tabular}{|c|c|c|}
\hline Category & Meaning Units (MU) & $\begin{array}{l}\text { MU } \\
\text { Code }\end{array}$ \\
\hline \multirow{8}{*}{$\begin{array}{l}\text { Human } \\
\text { Capital }\end{array}$} & $\begin{array}{l}\text { Subordinates learning from } \\
\text { leader's experience and } \\
\text { knowledge }\end{array}$ & H1 \\
\hline & $\begin{array}{l}\text { Subordinate's confidence of } \\
\text { Leader's Experiential Knowledge }\end{array}$ & $\mathrm{H} 2$ \\
\hline & Reciprocal/collaborative learning & $\mathrm{H} 3$ \\
\hline & $\begin{array}{l}\text { Leader guiding of subordinate's } \\
\text { learning }\end{array}$ & $\mathrm{H} 4$ \\
\hline & $\begin{array}{l}\text { Role modeling of leader by } \\
\text { subordinates }\end{array}$ & H5 \\
\hline & Leader's accredited knowledge & H6 \\
\hline & Leader's reputation & $\mathrm{H7}$ \\
\hline & Leader's de-motivating influence & H8 \\
\hline \multirow{4}{*}{$\begin{array}{l}\text { Emotional } \\
\text { Capital }\end{array}$} & $\begin{array}{l}\text { Leader's respectfulness to } \\
\text { subordinate }\end{array}$ & E1 \\
\hline & $\begin{array}{l}\text { Leader possessing likeable and } \\
\text { inspiring traits }\end{array}$ & E2 \\
\hline & $\begin{array}{l}\text { Leader's compassion to } \\
\text { subordinate }\end{array}$ & E3 \\
\hline & $\begin{array}{l}\text { Leader is supportive and } \\
\text { nurturing towards subordinate }\end{array}$ & E4 \\
\hline
\end{tabular}


traits, (3) compassion, and (4) supportive and nurturing. Each meaning unit has at least one interviewee citing it.

\subsection{Thematic Finding}

A theme is an underlying topic or matter found among all the interviewees whether through their categories, meaning units, excerpts and transcripts. All the interviewees' cited Learning from Leader's Experience and Knowledge meaning unit (Human Capital Category) and the leader being Respectful meaning unit (Emotional Capital Category). Thus, one theme emerged from the subsequent interpretative analysis of the transcripts, excerpts, meaning units and categories. The theme is "Creativity is encouraged through learning from leader's superior human capital. The learning is aided by the leader's emotional capital" (Table 2).

Design subordinates' creativity is encouraged by their confidence in and learning from the leaders' human capital especially the experiential knowledge. All the interviewees cited the meaning unit 'subordinate's learning from the leader's experience and knowledge'. The leader's reputation in the industry and relevant accredited qualifications contribute to this confidence about the superiority of the leader's human capital. Yet, Architect R1 said that having higher degrees is not important for architecture creativity. Although Engineer E1 prioritized learning from the leader's experience, he contradicted by saying that in engineering field, a strong structural design theoretical background is needed to design satisfactorily and make subordinate confident about leader's human capital. It implies that Engineer E1 wanted to ensure that the experiential knowledge received from the leader is not flawed. It seemed that the leader's accredited knowledge is more important for subordinates who work in Malaysian provincial cities such as Kota Kinabalu in the state of Sabah where experiential learning opportunities for subordinates are less.

"Definitely. I agree with that (Statement: Work subordinates are more likely to be influenced by a manager to be creative because the manager has work skills, knowledge and experiences that the subordinates want to learn from). Because he is your superior. In terms of qualification, experience and everything, he is better than you. So, of course you will be influenced by him. Whoever enters a firm or company, he or she may have certain experiences that affect how he or she designs. In a 'fresh' project, we come to learn. If we gain experience, we can use it to apply for a better new job or a better position, but nevertheless, there will be some (persons in the new firm) who are "higher" than you in term of experience and knowledge.....In Malaysia, I can see that especially in Sabah, East Malaysia where I work now, a lot of, 100 percent (of subordinates) are influenced by their superiors."

Architecture Interviewee R5.
The leader's emotional capital makes the subordinate confident that he/she will be able to attain the superior human capital from the leader. The leader's positive emotional capital namely being likable, compassionate, respectful toward the subordinate's abilities and designs is believed to show the leader's generosity, willingness

Table 2 Interviewee Meaning Unit Matrix

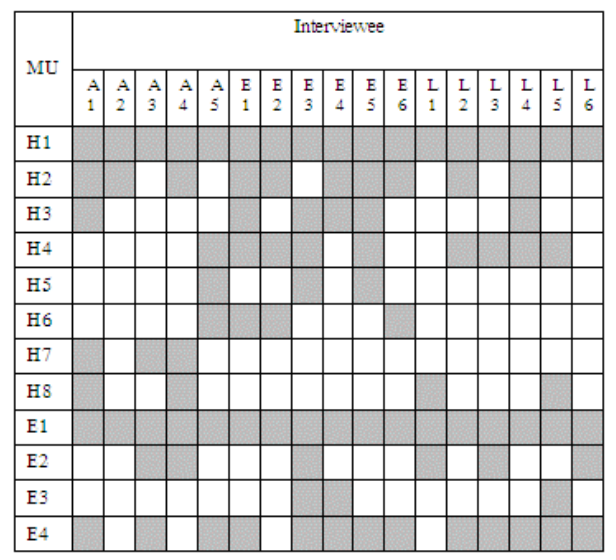

Key: MU=Meaning Unit; $\quad$ A=Architecture;

$E=$ Engineering; $L=$ Landscape Architect

Shaded box indicates presence of meaning unit (MU) in respective interviewee's responses.

and supportiveness to helping the subordinate learn further either through work interactions, mentoring or nurturing methods.

"Although a subordinate is still 'learning', he has his own ideas. So the manager, however senior he is, should respect these new ideas. He should not show his 'power' and reject the ideas just because he has been designing longer...At the start, the subordinate has to obey his manager but slowly and surely he must show and prove his creativity to his manager. His designs must be workable, so he has to work hard."

Architecture Interviewee R3

"When the design comes from the boss, the boss will accept any discussion with the stuff. He will ask me the reason for designing a certain way. So, we give our reasons. When we input our best ideas into the design, we can easily discuss with the boss.....but here we can discuss with boss about our design...If we feel our ideas on the detailing is better, he will have a look and give his consent for inclusion into the design. For him

to give consent, we have to give reasons and show some sketches of alternative designs first." Landscape architecture Interviewee L1

\section{Discussion}

Bourdieu [12] specified three types of capitals, namely economic, social and cultural capitals. However, the human and emotional capitals of this paper are different manifestations of Bourdieu's cultural capital. According 
to Bourdieu, there are three types of cultural capital. The first type is embodied cultural capital which refers to long lasting dispositions of the mind and behaviours that are nurtured. This definition would encompass the study's emotional capital. The second type of cultural capital is institutionalized cultural capital which is defined as accredited knowledge and skills objectified through academic qualifications and formalized titles. This would be partially similar with human capital of this study. However, Bourdieu's institutionalized cultural capital excludes tacit experiential knowledge critical to professional practice. Lastly, objectified cultural capital refers to the person's possession material objects and media that stylistically reflect his status in the community. The forms of embodied and institutionalized cultural capital are found the human capital and emotional capital categories uncovered in this study.

The analysis indicated that the leader's emotional capital and superior human capital influence the design subordinates' creativity. There are two possible reasons for this finding. Firstly, design consultants are in the knowledge economy business. They use their human capital to provide designs needed by the clients. Hence, a leader's human capital is important for generating creative products and thus the sustainability of his firm. The leader is aware that his subordinates are instrumental to these creative product generation. Hence, his/her creativity is dependent on the creativity of his subordinates. He knows that if he/she does not enhance his subordinates' human capital, their creativity is limited. The leader's respect for the subordinate's design abilities and output reflects the collaborative nature of design work in a consultant firm. When a leader shows respect to his subordinate's creative output, it eases this collaboration. The subordinate does not fear that his creative works being sidelined by the leader. He also senses the importance of human capital in the firm he works in. The subordinate is furthermore aware that the firm's designs are a team effort based upon the main design concepts of his leader. Hence, his job security is enhanced if he has the needed human capital that contributes positively to the team effort. Thus, he is motivated to enhance his human capital. An easily available source of human capital enhancement is his leader at the workplace.

The second possible reason is related to design consultant firms in the construction industry being mostly small enterprises. Their small sizes do not give enough financial capability to regularly sponsor their employees for training to enhance their skills and knowledge, and consequently their design creativity [26]. Thus, the employees are probably dependent upon their leaders to provide the enhancement free of financial costs.

Leadership is commonly defined as the ability of an individual to influence, motivate and enable others to contribute towards the effectiveness and success of their affiliated organization [27]. The common goals of the subordinates in this study were found to include their enhanced human capital. The leader can influence his subordinates' creativity through the possible learning of his/or superior human capital. In other words, the leader's human capital contributes to his/her leadership capital. The responses indicated that the transfer of human capital is both transformative and transactional.

A potential deficiency of the findings is the use of three different professions in the analysis. It may be argued that each profession has its own doxa and habitus. Engineering and architecture consultants are licensed in Malaysia while landscape architecture consultants depend on their professional society's accreditation for credibility. Thus, it may be inappropriate to use these three professions together. However, a person simultaneously dwells in many 'fields of practice', such as simultaneously having an architecture 'field' and a construction industry 'field' [12]. The interviewees' responses were also relatively similar and theoretical saturation was achieved relatively early (at the sixteenth interviewee). The three professions also operate in the same industry, implying possessing the doxa and habitus of the construction industry 'field of practice'.

\section{Conclusion}

The theme " "Creativity is encouraged through learning from leader's superior human capital. The learning is aided by the leader's emotional capital" was generated from the analysis of the interviews. This theme implies that Bourdieu capitals are instrumental within sociocultural and economic contexts in influencing subordinates' creativity. Thus, Bourdieu capitals offer an innovative perspective in studying and possibly quantifying leaders' influence upon their followers.

\section{Acknowledgement}

The Authors are grateful to the Malaysia MOHE (Ministry of Higher Education) for financing the research under the Fundamental Research Grant Scheme (FRGS), 600-RMI/FRGS 5/3 (16/2014) monitored by Universiti Teknologi Mara (UiTM).

\section{References}

1. M. Roy, "Charting the evolving landscape of services trade: Recent patterns of protection and liberalization," in M. Roy and P. Sauvé (eds.), Research Handbook on Trade in Services, pp25-41. Northampton, Mass.: Edward Elgar, (2016)

2. MATRADE. Free Trade Agreements. Malaysia External Trade Development Corporation (MATRADE). Retrieved from http://www.matrade.gov.my/en/malaysianexporters/going-global/understanding-free-tradeagreements (2017, September 18)

3. Anon., Construction Industry Transformation Programme 2016-2020 - Driving Construction Excellence Together. Retrieved from http://www.citp.my/ (2017, September 18)

4. E. Mulet, M. Royo, V. Chulvi, \& G. Galá, Relationship between the degree of creativity and the quality of design outcomes. DYNA 84(200), 3845 (2017) 
5. M.A.Runco, and G.J. Jaeger, The Standard Definition of Creativity . Creativity Research Journal, 24(10), 92-96 (2012)

6. R. K. Sawyer, Explaining Creativity: The Science of Human Innovation. New York: Oxford University Press, (2012)

7. D. Valgeirsdottir, and B. Onarheim, Metacognition in Creativity: Process Awareness Used to Facilitate the Creative Process. In Christensen, B.T., Ball, L.J., Halskov, K. (eds). Analysing Design Thinking: Studies of Cross-Cultural Co-Creation, Chapter 12. CRC Press (2017)

8. J.J. Sosik, S.S. Kahai, and B.J. Avolio, Transformational leadership and dimensions of creativity: motivating idea generation in computermediated groups, Creativity Research Journal, 11(2), 111-121 (2017)

9. D. Politis The process of entrepreneurial learning: a conceptual framework. Entrepreneurship Theory and Practice 29(4) 399-424, (2005)

10. P. Wang and J Rode Transformational leadership and follower creativity: the moderating effects of identification with leader and organizational climate. Human relations 63(8), 1105-1128 (2010)

11. Y. Dong, K.M. Bartol, Z.X. Zhang, and C. Li, Enhancing employee creativity via individual skill development and team knowledge sharing: Influences of dual-focused transformational leadership. Journal of Organizational Behavior, 38, 439-458 (2017)

12. P. Bourdieu. The forms of capital. In Richardson, J. (ed), Handbook of Theory and Research for the Sociology of Education, (pp.241-258). Westport, CT: Greenwood, (1986).

13. V. Venkataramani, L. Zhou, M. Wang, H. Liao, and J. Shi. Social networks and employee voice: the influence of team members' and team leaders' social network positions on employee voice Org. Behavior and Human Decision Processes 132, $37-$ 48 (2016)

14. P. Bourdieu. La Distinction: a social critique of the judgement of taste (R Nice, Trans.) Cambridge, MA: Harvard University Press, (1984)

15. H. Santos-Rodrigues, P.F. Dorrego, \& C.F. Jardon, The influence of human capital on the innovativeness of firms. The International Business \& Economics Research Journal, 9(9), 53-63 (2010)

16. C.C. Liu, S.Y. Chen and C.H. Liao. The relationships among emotional capital, job satisfaction and organizational citizenship behavior: a cross-level analysis. Chiao Da Management Review, 35(1) 1-24 (2015)

17. R. Landry, N. Amara and M. Lamari. Does social capital determine innovation? to what extent? Technological Forecasting and Social Change, 69 (7), 641-764 (2000)

18. A. Perez-Luno, C.C. Medina, A. C. Lavado, and G.C. Rodriguez How social capital and knowledge affect innovation. Journal of Business Research, 64 (12), 1259-1382 (2011).

19. J. Gu, Y. Zhang, and H. Liu. Importance of social capital to student creativity within higher education in China. Thinking Skills and Creativity, 12, 14-25 (2014).

20. J.P. Spillane, T. Hallett, and J.B. Diamond, Forms of Capital and the Construction of Leadership: Instructional Leadership in Urban Elementary Schools. Sociology of Education, 76(1), 1-17, (2003).

21. A. West, and L. Allin. Does play pay? The production and conversion of physical capital by sports coaches and outdoor leaders in the UK. International Review of Women and Leadership,

$6(2), 5$ (2000)

http://sure.sunderland.ac.uk/id/eprint/3354

22. J. Zacharakis and J. Flora. Riverside: A Case Study of Social Capital and Cultural Reproduction and their Relationship to Leadership Development. Adult Education Quarterly, 55(4) 288-307 (2005)

23. O. Levy, S. Taylor, N. A. Boyacigiller, T. E. Bodner, M.A. Peiperl, and S. Beechler. Perceived senior leadership opportunities in MNCs: The effect of social hierarchy and capital. Journal of International Business Studies, 46(3), 285-307 (2015)

24. E. Keskiner and M. Crul. How to reach the top? Fields, forms of capital, and strategies in accessing leadership positions in France among descendants of migrants from Turkey. Ethnic and Racial Studies, 40(2), 283-300, (2017).

25. M. Bennister, B. Worthy, and P. Hart, Assessing the authority of political office-holders: the leadership capital index. West European Politics, 38(3), 41744-, (2014)

26. A. Y. Moohammad, Y. Nor'Aini, and E. M. Kamal. Influences of Firm Size, Age and Sector on Innovation Behaviour of Construction Consultancy Services Organizations in Developing Countries. Business Management Dynamics, 4(4) 01-09, (2014)

27. J. M. George, and G. R. Jones, G. R. (2012). Understanding and Managing Organizational Behavior (6th ed.). New York, NY: Prentice Hall, (2012) 